\title{
Critical Review and Evaluation of Composite/Ceramic Onlaysversus Crowns
}

\author{
Fotoula Nikolopoulou ${ }^{1 *}$ and Michael Loukidis ${ }^{2}$
}

${ }^{1}$ Department of Prosthodontics, Dental school, University of Athens, Greece

${ }^{2}$ Department of Operative Dentistry, Dental school, University of Athens, Greece

${ }^{*}$ Corresponding author: Dr. Fotoula Nikolopoulou, MD, DDS, MPH, PhD, Asst.Proffesor, Department of Prosthodontics, Dental school, University of Athens, Greece, Tel: +302106411926; E-mail: fnikolop@dent.uoa.gr ; fotoulan@pitt.edu

Rec Date: July 07, 2014; Acc Date: Oct 25, 2014; Pub Date: Nov 1, 2014

Copyright: (c) 2014 Nikolopoulou F et al., This is an open-access article distributed under the terms of the Creative Commons Attribution License, which permits unrestricted use, distribution, and reproduction in any medium, provided the original author and source are credited.

\begin{abstract}
The purpose of this comprehensive review was to evaluate and identify the performance of composite/ceramic onlays versus crowns. The strength of the evidence is based on published trials, systematic reviews and observational studies.

Methods: The dental literature was reviewed for controlled clinical studies and retrospective cross-sectional studies from 1966 to 2013. Longevity of onlay or crown is dependent upon many different factors, including material, patient-and dentist-related. Principal reasons for failure were secondary caries fractures, marginal deficiencies, wear and postoperative sensitivity.

Minimally invasive dentistry, in cases in which it is appropriate, is a concept that preserves dentition, supports structures and involves low cost therapy.
\end{abstract}

Keywords: Onlay; Crown; Composite resin; Porcelain laminate veneers

\section{Introduction}

The aim of this comprehensive review of the relevant literature was to evaluate the extra coronal restorations.

The choice of restoration depends on the amount of the remaining tooth which may influence long term survival and cost. An intermediate technique consists of manufacturing an onlay. This is a conservative solution. Many innovative techniques and materials have been introduced into dentistry during the past two decades, such as ultra conservative cavity preparation, modern dentin adhesives, hybrid-type resin composites ceramic onlays and inlays. Onlays can be made of metal alloys, ceramic or composite materials [1].

The chemical composition differs between ceramic and composite onlays. This explains most of their clinical properties. Ceramic onlays are mainly composed of glass, with some crystals added to increase strength [2]. Ceramic materials are resistant to compressive forces but are susceptible to tensile stresses [3].

It is known that an occlusal cavity restoration reduce tooth stiffness by $20 \%$, whilst a mesial-occlusal-distal (MOD) cavity preparation by $63 \%$ [4]. Although the MOD (mesial-occlusal-distal) onlay is a variation of the class II inlay, there are enough distinct differences between the two restorations that the onlay merits consideration as a separate type of cast restoration. It has been reported by Craig et al that photoelastic stress analysis showed the superiority of the MOD onlay in protecting teeth from stress $[5,6]$.

It has been reported that onlays and overlays have been proposed for restoring root filled teeth [7]. The fabrication of indirect ceramic or resin composite onlays may permit greater control over occlusal and proximal contacts and reduce the negative effect of polymerization shrinkage when compared to direct restorations [8].

When a substantial part of the facial or lingual surface of a tooth has been destroyed an alternative restoration must be selected. The porcelain-fused-to-metal restoration is a combination of esthetic porcelain veneering material and a metal substructure. There is no question as to their acceptability and resistance to fracture and abrasive wear; these are the major advantages of full-coverage restorations $[9,10]$. While a porcelain-fused-to-metal crown can serve as a strong and esthetic restoration, patients too often receive this type of restorations for minor irregularities that could have been better handled by conservative treatment [11].

It has been reported that distortion related to margin design in porcelain-fused-to-metal restoration creates a space for accumulation of bacterial plaque which could lead to gingival inflammation [12]. Ceramics with framework of zirconium oxide have high fracture strength and high survival rates clinically [13].

\section{Methods}

We did a systematic review of strategies and methods describing the treatment of teeth with onlay or crown and the subsequent clinical of failure of these restorations. Approximately articles were included in this review based on a MED-LINE and PubMed search of English language. The criteria for selection of this review were; randomized controlled trials, nonrandomized controlled trials, experimental clinical studies, prospective studies and retrospective studies.

In 1988 Wendt and Leifelder clearly demonstrated that the polymerization shrinkage of heat-cured composite onlay occurs before the restoration is plased [14]. The justification for the use of heatcured composite onlay over direct-placed composite restorations has been questioned by Bertolotti [15]. Many studies have compared 
Page 2 of 6

ceramic onlay with composite onlay. Ceramic ones are resistant to compressive forces but are susceptible to tensile stresses and more prone to fracture then are composite onlays $[3,16,17]$. Nine clinical studies have evaluated ceramic and composite materials for onlays[18-26]. Yet, we can draw no definite conclusions on the best material for onlay from these studies.

In 1997 Fradeani and other investigators reported on the performance of 125 IPS-Empress inlay and onlay restorations. Only 18 of these restorations were onlays, $60 \%$ of the restorations were followed for up to 56 months. Apart from 4 restorations that underwent bulk fracture, the remaining were rated as either "good" or "satisfactory" according the modified United States Public Health Service (USPHS) criteria that were used for their evaluation. Estimated survival was $96 \%$ at 4.5 years [27].

In 1998, Lehneret al. carried out a clinical trial involving 138 inlays and 17 onlays. The restorations were placed by 18 clinicians who used calibrated technique in a university clinic. After 5.3 years 7 restorations were judged as clinical failures. The Kaplan-Meier survival rate had dropped to $91 \%$ at 7 years [28].

In 2000 few researchers conducted a controlled prospective clinical trial of IPS-Empress inlays and onlays. After six years the survival rate was calculated as $93 \%$. The authors concluded that restorations of larger cavities in molars performed satisfactorily and that cuspal reconstruction was not a limiting factor for clinical success [19]. Few studies showed no significant difference between direct and indirect techniques, with the lower failure rates being observed for the direct onlay technique. These clinical studies demonstrated the advantage of the direct method compared to the indirect technique [29-31].

There was one clinical study examining the long-term effectiveness of posterior indirect resin composite onlays and cast-gold restorations at 7 years. The restorations that have been placed in the 18 patients who returned for the 7 year recall examination included 7 gold onlays, 4 concept indirect resin composite onlays, 11 gold inlays and 32 concept indirect resin composite inlays. They concluded that the overall failure rate of indirect resin composite onlays was not significantly different from that of gold onlays [32].

In 2001, Hickel and Manhart referred an annual failure of 2.3\% (range $0-11.8 \%$ ) for composite inlays and onlays, as compared with $1.3 \%$ (range $0-7.5 \%$ ) for ceramic inlays and onlays, which were evaluated in longitudinal studies [33,34]. Kaytan et al. compared the clinical performance of ceramic onlays and indirect resin composite over a 24-month period and concluded that both of them were successful clinically [35].

Salameh et al. investigated in vitro the fracture resistance of endodontically treated teeth restored with different onlay restorations. The onlays were made from gold, ceramic and resin composite. They showed that restoration of endodontically treated teeth with gold onlays improved fracture resistance when compared to glass ceramic or resin composite onlays [36].

In 2011 Magne et al. evaluated in vitro the pre-cementation resistance of CAD/CAM onlays subjected to functional occlusal tapping. They pointed out the selection of the material had a significant effect on the risk of CAD/CAM onlay fracture during precementation functional occlusal tapping with composite resin onlays showing the minimum risk compared to ceramic ones [37]. In 2012 Kois et al. in experimental study evaluated the load-fatigue performance of ceramic onlay restorations with or without buccal veneers and the existing amount of tooth structure (non-worn tooth, worn tooth). Ceramic fracture occurred only in the group of worn tooth [38].

\section{Clinical evaluation direct and indirect composite onlay}

The US Public Health Service (USPHS) evaluation system is the most commonly used direct method for quality control of restoration. It was designed to reflect differences in acceptability (yes/no) rather than in degrees of success [39] (Tables 1 and 2).

\begin{tabular}{|c|c|c|c|c|c|}
\hline Author & $\mathrm{Nr}$ restor. & Direct & Indirect & $\begin{array}{l}\text { Clinical } \\
\text { Performance }\end{array}$ & Material \\
\hline Kyou-Li Kim et al. [40] & 967 & 676 & & Acceptable & Composite resin \\
\hline \multirow[t]{2}{*}{ Cetin A \&Unlu N [41] } & 100 & 50 & & Acceptable & Composite nanohybrid \\
\hline & & & 50 & Acceptable & Hybrid ceramic \\
\hline Kramer $N$ et al [42] & 96 & 96 & & Failure of 7 & IPS Empress \\
\hline \multirow[t]{2}{*}{ Kuijs et al [43] } & 54 & 20 & & $40 \%$ postoperative sensitivity & Composite \\
\hline & 54 & & 34 & Caries $58.82 \%$ & Composite \\
\hline \multirow[t]{2}{*}{ Hickel R [33] clinical rev. } & & + & & $9 \%$ failure & Composite \\
\hline & & + & & $4.4 \%$ failure & Ceramic \\
\hline \multirow[t]{2}{*}{ Manhart J et al. review [44] } & & 51 & & $2 \%$ failure & Composite \\
\hline & & & 19 & $1.4 \%$ failure & Cast gold \\
\hline Dijken J WV [29] & 100 & 33 & & $27.3 \%$ unacceptable & Composite resin \\
\hline Kevin et al. [32] & 54 & & 18 & $\begin{array}{l}3 \text { failure } \\
16 \%\end{array}$ & Cast gold \\
\hline
\end{tabular}


Citation: Nikolopoulou E, Loukidis M (2014) Critical Review and Evaluation of Composite/Ceramic Onlaysversus Crowns. Dentistry 4: 261. doi:

Page 3 of 6

\begin{tabular}{|l|l|l|l|l|l|}
\hline & & 36 & & 9 failure secondary caries 25\% & Resin composite \\
\hline Chrepa et al. [45] & & & 189 & $1.1 \%$ failure & Resin \\
\hline Bartlett D, Sunderman [46] & 32 & 9 & 7 & Acceptable & Comp. resin \\
\cline { 2 - 6 } & & 3 & 4 & Failure (fracture) & Com. resin \\
\cline { 2 - 6 } & & 4 & 5 & Lost & Comp.resin \\
\hline
\end{tabular}

Table 1: Evaluation of Direct Indirect onlay

\begin{tabular}{|l|l|l|l|}
\hline Author & Nr. specimens & Material & Results \\
\hline Belli et al. [47] & 10 & $\begin{array}{l}5 \text { ceramic } \\
5 \text { composite }\end{array}$ & $\begin{array}{l}\text { Equivalent fatigue strength } \\
\text { degradation at lods } 0.56 \text { in }\end{array}$ \\
\hline Beatriz et al. [48] & 70 & $\begin{array}{l}\text { Vitadur Alpha } \\
\text { Ceramic } \\
\text { Different cements }\end{array}$ & Showed lower fracture resistance \\
\hline Suzuki et al. [49] & 7 & $\begin{array}{l}\text { Indirect compos. } \\
(2 \text { photo, } 5 \text { photo/heat) }\end{array}$ & Wear resistance similar to type III gold alloy tested \\
\hline Magne P et al. & 14 onlay & $\begin{array}{l}\text { Paradigm MZ100 } \\
\text { e-max CAD \&Markll }\end{array}$ & Survival rate 36\%. Failure at av. load 157N \& 123N \\
\hline Morito S et al. [50] & 30 maxillary premolars & $\begin{array}{l}\text { Ceramic } \\
\text { Composite }\end{array}$ & $\begin{array}{l}\text { Fracture ceramic/composite similar to impact teeth. } \\
57 \% \text { greater ability to absorb impacts than ceramic }\end{array}$ \\
\hline
\end{tabular}

Table 2: In-vitro evaluation onlay restorations

The porcelain-fused-to-metal restoration requires considerable reduction of tooth structure. It is known for a metal-ceramic shoulder preparation, a facial tooth reduction of about 1.3 to $1.5 \mathrm{~mm}$. In 1966 some clinicians reported that the invasive complete metal-ceramic crown has been correlated with increase pulpal complications. Radiographic periapical pathologies from 0.4 to $2 \%$ were found [51].

In $19702.9 \%$ periapical pathologies were reported [52]. About ten years later up to $4 \%$ were detected [53].

Some clinicians recommended onlay as retainers for short-span FPDsincaries-resistant dentitions. In addition to facilitating superior periodontal health, onlays enable the preservation of healthy tooth structure [1,54]. In 1970 Roberts referred that greater FPD longevity for complete crown retainers compared to onlays. The main causes of failures were secondary caries and loss of retention [54].

Some investigators in a prospective randomized controlled trial described that the survival rate of ceramic restorations was $95.1 \%$ matched that of gold crowns [55] (Table 3).

\begin{tabular}{|c|c|c|c|c|c|}
\hline Author & $\begin{array}{l}\text { Type of } \\
\text { study }\end{array}$ & Restorations & $\begin{array}{l}\text { Follow up } \\
\text { (months }\end{array}$ & $\begin{array}{l}\text { Failure } \\
\text { Cause }\end{array}$ & $\begin{array}{l}\text { Survival } \\
\text { rate }\end{array}$ \\
\hline Beier et al [56] & Retrospective & $\begin{array}{l}470 \text { crowns } \\
213 \text { onlays }\end{array}$ & $\begin{array}{l}102 \pm 60 \\
102 \pm 60\end{array}$ & $\begin{array}{l}\text { Bruxism } \\
\text { Non-vital teeth }\end{array}$ & $\begin{array}{l}93.5 \% \text { over } 10 \text { years } \\
75.5 \% \text { at } 5 \text { years }\end{array}$ \\
\hline Sjogren et al [57] & Retrospective & $\begin{array}{l}75 \text { crowns } \\
35 \text { onlays }\end{array}$ & 42 & Fracture & $92 \%$ at 3.5 years \\
\hline Sorensen et al [58] & Prospective clinical trial & 75 crowns & $14-42$ & Fracture & $99 \%$ at 3 years \\
\hline Fradeani [27] & Cases series & 144 crowns & $6-68$ & Core failure & $95 \%$ at 3 years \\
\hline Marguerito[59] & Prospective clinical trial & 210 onlays \& partial veneer crowns & 36 & fracture & \\
\hline
\end{tabular}

Table 3: Clinical evaluation of onlays and crowns 


\section{Discussion}

There is no comprehensive review of the relevant literature that identifies when onlay or crown can be used. The sea of information can overwhelm the clinician. The bewildered dentist is left with the question of which criteria one should employ to differentiate between onlays or crowns. The clinician needs to consider some factors when deciding to cover a cusp by an onlay. Many reasons have been given for the failure of ceramic onlays. The principal problems of these constructions to be related to cavity preparation, patient occlusion, cementing agents, insufficient thickness and internal defects of ceramics. If the intracoronal cut is less than one third of the distance from cusp tip to cusp tip, it is preference to place a direct resin composite [60]. It has been reported that $18-22 \%$ of crowns which are placed are all-ceramic. These crowns require tooth preparations that involve significant tooth reduction. If these tooth preparations are accomplished on a young person with large dental pulps, or a person with sensitive teeth, the result is predictable. These patients need endodontic therapy. The teeth described above may be restored using less aggressive tooth crown preparations. In this case more conservative and potentially longer-lasting restorations could be accomplished by preparing the tooth for onlay, thereby preserving the facial and lingual tooth surfaces [61-63].

Experimental study indicated cavity preparation for onlay is wider than half of the cusp tip to cusp tip distance increase the risk of splits or cracks [63]. A clinical study was carried out by Murgueitio and Bernal. They analyzed the survival rate mode of IPS-leucite-reinforced ceramic onlays and partial veneer crowns regarding thickness under the following clinical conditions: vital versus non vital teeth, tooth location and type of opposing dentition. They concluded that thickness of the restorations, tooth vitality and location of the teeth in the dental arch influenced restoration failures [64]. A complete crown preparation for cast-metal and metal ceramic has been correlated with an increase in pulpal complications. In 1966 only $0.4 \%$ to $2 \%$ radiographic periapical pathologies were found, whereas in $19702.9 \%$ was reported. Ten years later to $4.0 \%$ periapical pathologies were detected. These results are explained by the increased use of air turbines and more invasive shoulder or chamfer preparations for metal-ceramic restorations compared to the feather-edge design used in the 1960s and 1970s [1,65-67]. Nowadays all ceramic restorations have improved dramatically. Making tooth preparations for crowns is relatively easy, undoubtedly, that is one of the reasons that crowns are used more often than the slightly more difficult onlay.

It has been estimated that there are about 22,000 of its CEREC computer-aided design/computer-aided manufacturing (CAD/CAM) devices in offices around the world. The popularity of clinical CAD/CAM machines has stimulated dentists to provide more conservative restorations $[68,69]$.

Few studies concerning of cost-effectiveness have been of poor quality, and no valid comparison of the cost-effectiveness of different restorative materials used in dental practices in the same patient population have been published to date.

Kelly and Smales in their long-term cost-effectiveness of single indirect restorations reported that 1).The benefits of direct placement restorations include less discomfort and less removal of sound tooth substance with fewer biological consequences. 2) There was no support found for the practice of replacing large amalgam and resin composite restoration with onlay or crowns to prevent potential tooth fractures. 3) Indirect anterior restorations with ceramometal crowns were more cost-effective than porcelain jacket crowns [50].

The relevant literature offers little information regarding the decision about when to treat a patient with onlay or crown. We need more research on this issue for better clinical treatment of patients.

\section{References}

1. Edelhoff D, Sorensen JA (2002) Tooth structure removal associated with various preparation designs for posterior teeth. Int J Periodontics Restorative Dent 22: 241-249.

2. Lin WS, Ercoli C, Feng C, Morton D (2012) The effect of core material, veneering porcelain, and fabrication technique on the biaxial flexural strength and weibull analysis of selected dental ceramics. J Prosthodont 21: 353-362.

3. FronChabouis H, SmailFaugeron V, Attal JP (2013) Clinical efficacy of composite versus ceramic inlays and onlays: a systematic review. Dent Mater 29: 1209-1218.

4. Reeh ES, Messer HH, Douglas WH (1989) Reduction in tooth stiffness as a result of endodontic and restorative procedures. J Endod 15: 512-516.

5. Craig RG, el-Ebrashi MK, LePeak PJ, Peyton FA (1967) Experimental stress analysis of dental restorations. I. Two-dimensional photoelastic stress analysis of inlays. J Prosthet Dent 17: 277-291.

6. Fisher DW, Caputo AA, Shilingburg HI, Duncanson MG (1975)Photoelastic analysis of inlay and onlay preparations. J Prosthet Dent 33: 47-50.

7. Jiang W, Bo H, Yongchun G, Long Xing N (2010) Stress distribution in molars restored with inlays or onlays with or without endodontic treatment: a three-dimensional finite element analysis. J Prosthet Dent 103: 6-12.

8. Hurth KC, Chen HY, Mebl A, Hickel R, Manhart J (2011) Clinical study of indirect composite resin inlays in posterior stress-bearing cavities placed by dental students: results after 4 years. J Dent 39:478-88.

9. Christensen GJ (1999) Ceramic veneers: state of the art, 1999. J Am Dent Assoc 130: 1121-1123.

10. Crispin BJ (1979) Conservative alternative to full esthetic crowns. J Prosthet Dent 42: 392-397.

11. Christensen GJ (2005) The advantages of minimally invasive dentistry. J Am Dent Assoc 136: 1563-1565.

12. Faucher RR, Nicholls JI (1980) Distortion related to margin design in porcelain-fused-to-metal restorations. J Prosthet Dent 43: 149-155.

13. Jongsma LA, Kleverlaan CJ, Feilzer AJ (2012) Clinical success and survival of indirect resin composite crowns: results of a 3-year prospective study. Dent Mater 28: 952-960.

14. Wendt SL, Leinfelder KF (1988) Clinical evaluation of a heat cured composite inlay. J Dent Res 67:120.

15. Bertolotti RL (1991) Total etch--the rational dentin bonding protocol. J Esthet Dent 3: 1-6.

16. Magne P, Belser UC (2003) Porcelain versus composite inlays/onlays: effects of mechanical loads on stress distribution, adhesion, and crown flexure. Int J Periodontics Restorative Dent 23: 543-555.

17. Yamanel K, Caglar A, Gülsahi K, Ozden UA (2009) Effects of different ceramic and composite materials on stress distribution in inlay and onlay cavities: 3-D finite element analysis. Dent Mater J 28: 661-670.

18. Dukic W, Dukic OL, Milardovic S, Delija B (2010) Clinical evaluation of indirect composite restorations at baseline and 36 months after placement. Oper Dent 35: 156-164.

19. Frankenberger R, Petschelt A, Krämer N (2000) Leucite-reinforced glass ceramic inlays and onlays after six years: clinical behavior. Oper Dent 25: 459-465.

20. Frankenberger R, Taschner M, Garcia-Godoy F, Petschelt A, Krämer N (2008) Leucite-reinforced glass ceramic inlays and onlays after 12 years. J Adhes Dent 10: 393-398. 
21. Krämer N, Taschner M, Lohbauer U, Petschelt A, Frankenberger R (2008) Totally bonded ceramic inlays and onlays after eight years. J Adhes Dent 10: 307-314.

22. Krämer N, Frankenberger R (2005) Clinical performance of bonded leucite-reinforced glass ceramic inlays and onlays after eight years. Dent Mater 21: 262-271.

23. Monaco C, Baldissara P, dall'Orologio GD, Scotti R (2001) Short-term clinical evaluation of inlay and onlay restorations made with a ceromer. Int J Prosthodont 14: 81-86.

24. Otto T, De Nisco S (2002) Computer-aided direct ceramic restorations: a 10 -year prospective clinical study of Cerec CAD/CAM inlays and onlays. Int J Prosthodont 15: 122-128.

25. Posselt A, Kerschbaum T (2003) Longevity of 2328 chairsideCerec inlays and onlays. Int J Comput Dent 6: 231-248.

26. Schulte AG, Vöckler A, Reinhardt R (2005) Longevity of ceramic inlays and onlaysluted with a solely light-curing composite resin. J Dent 33: 433-442.

27. Fradeani M, Aquilano A, Bassein L (1997) Longitudinal study of pressed glass-ceramic inlays for four and a half years. J Prosthet Dent 78: 346-353.

28. Lehner C, Studer S, Brodheck U, Scharer P (1998) Six-year clinical results of leucite-reinforced glass ceramic inlays and onlays. Acta Med Dent Helv 3:137-146.

29. Van Dijken JW (2000) Direct resin composite inlays/onlays: an 11 year follow-up. J Dent 28: 299-306.

30. Peutzfeldt A, Asmussen E (1990) A comparison of accuracy in seating and gap formation for three inlay/onlay techniques. Operat Dent 15:129-135.

31. van Dijken JW (1994) A 6-year evaluation of a direct composite resin inlay/onlay system and glass ionomer cement-composite resin sandwich restorations. ActaOdontolScand 52: 368-376.

32. Donly KJ, Jensen ME, Triolo P, Chan D (1999) A clinical comparison of resin composite inlay and onlay posterior restorations and cast-gold restorations at 7 years. Quintessence Int 30: 163-168.

33. Hickel R, Manhart J (2001) Longevity of restorations in posterior teeth and reasons for failure. J Adhes Dent 3: 45-64.

34. Davidowitz G, Kotick PG (2011) The use of CAD/CAM in dentistry. Dent Clin North Am 55: 559-570.

35. Kaytan B, Onal B, Pamir T, Tezel H (2005) Clinical evaluation of indirect resin composite and ceramic onlays over a 24 -month period. Gen Dent 53: 329-334.

36. Salameh Z, Ounsi HF, Aboushelib MN, Al-Hamdan R, Sadig W, et al. (2010) Effect of different onlay systems on fracture resistance and failure patterns of endodontically treated mandibular molars restored with and without glass fiber posts. Am J Dent23:81-86.

37. Magne P, Schlichting LH, Paranhos MP (2011) Risk of onlay fracture during pre-cementation functional occlusal tapping. Dent Mater 27:942-947.

38. Kois DE, Chaiyabutr Y, Kois JC (2012) Comparison of load-fatigue performance of posterior ceramic onlay restorations under different preparation designs. CompendContinEduc Dent 33 Spec No 2: 2-9.

39. Manhart J, Neuerer P, Scheibenbogen-Fuchsbrunner A, Hickel R (2000) Three-year clinical evaluation of direct and indirect composite restorations in posterior teeth. J Prosthet Dent 84: 289-296.

40. Kim KL, Namgung C, Cho BH (2013) The effect of clinical performance on the survival estimates of direct restorations. Restor Dent Endod 38: $11-20$.

41. Cetin AR, Unlu N (2009) One-year clinical evaluation of direct nanofilled and indirect composite restorations in posterior teeth. Dent Mater J 28: 620-626.

42. Krämer N, Frankenberger R, Pelka M, Petschelt A (1999) IPS Empress inlays and onlays after four years--a clinical study. J Dent 27: 325-331.

43. Kuijs RH, Fennis WM, Kreulen CM, Roeters FJ, Creugers NH, et al. (2006) A randomized clinical trial of cusp-replacing resin composite restorations: efficiency and short-term effectiveness. Int J Prosthodont 19: 349-354.

44. Manhart J, Chen H, Hamm G, Hickel R (2004) Buonocore Memorial Lecture. Review of the clinical survival of direct and indirect restorations in posterior teeth of the permanent dentition. Oper Dent 29: 481-508.

45. Chrepa V, Konstantinidis I, Kotsakis GA, Mitsias ME (2014) The survival of indirect composite resin onlays for the restoration of root filled teeth: a retrospective medium-term study. IntEndod J 47: 967-973.

46. Bartlett D, Sundaram G (2006) An up to 3-year randomized clinical study comparing indirect and direct resin composites used to restore worn posterior teeth. Int J Prosthodont 19: 613-617.

47. Belli R, Geinzer E, Muschweck A, Petschelt A, Lohbauer U (2014) Mechanical fatigue degradation of ceramics versus resin composites for dental restorations. Dent Mater 30: 424-432.

48. Cubas GB, Habekost L, Camacho GB, Pereira-Cenci T (2011) Fracture resistance of premolars restored with inlay and onlay ceramic restorations and luted with two different agents. J Prosthodont Res 55: 53-59.

49. Suzuki S, Nagai E, Taira Y, Minesaki Y (2002) In vitro wear of indirect composite restoratives. J Prosthet Dent 88: 431-436.

50. Morimoto S, Vieira GF, Agra CM, Sesma N, Gil C (2009) Fracture strength of teeth restored with ceramic inlays and overlays. Braz Dent J 20: 143-148.

51. Ericson S, Hedegård B, Wennström A (1966) Roentgenographic study of vital abutment teeth. J Prosthet Dent 16: 981-987.

52. Schwartz NL, Whitsett LD, Berry TG, Stewart JL (1970) Unserviceable crowns and fixed partial dentures: life-span and causes for loss of serviceability. J Am Dent Assoc 81: 1395-1401.

53. Langeland K, Langeland LK (1970) Pulp reactions to cavity and crown preparation. Aust Dent J 15: 261-276.

54. Roberts DH (1970) The failure of retainers in bridge prostheses. An analysis of 2,000 retainers. Br Dent J 128: 117-124.

55. Encke BS, Heydecke G, Wolkewitz M, Strub JR (2009) Results of a prospective randomized controlled trial of posterior $\mathrm{ZrSiO}(4)$-ceramic crowns. J Oral Rehabil 36: 226-235.

56. Beier US, Kapferer I, Dumfahrt H (2012) Clinical long-term evaluation and failure characteristics of 1,335 all-ceramic restorations. Int J Prosthodont 25: 70-78.

57. Sjögren G, Lantto R, Granberg A, Sundström BO, Tillberg A (1999) Clinical examination of leucite-reinforced glass-ceramic crowns (Empress) in general practice: a retrospective study. See comment in PubMed Commons below Int J Prosthodont 12: 122-128.

58. Sorensen JA, Choi C, Fanuscu MI, Mito WT (1998) IPS Empress crown system: three-year clinical trial results. J Calif Dent Assoc 26: 130-136.

59. Murgueitio R, Bernal G (2012) Three-year clinical follow-up of posterior teeth restored with leucite-reinforced ips empress onlays and partial veneer crowns. J Prosthodont 21: 340-345.

60. Christensen GJ (2008) Considering tooth-colored inlays and onlays versus crowns. J Am Dent Assoc 139: 617-620.

61. Christensen GJ (2002) Has tooth structure been replaced? See comment in PubMed Commons below J Am Dent Assoc 133: 103-105.

62. Christensen GJ (1999) Intracoronal and extracoronal tooth restorations 1999. See comment in PubMed Commons below J Am Dent Assoc 130: 557-560.

63. Geurtsen W, Schwarze T, Günay H (2003) Diagnosis, therapy, and prevention of the cracked tooth syndrome. See comment in PubMed Commons below Quintessence Int 34: 409-417.

64. Murgueitio R, Bernal G (2012) Three-year clinical follow-up of posterior teeth restored with leucite-reinforced ips empress onlays and partial veneer crowns. See comment in PubMed Commons below J Prosthodont 21: 340-345.

65. Maryniuk GA, Schweitzer SO, Braun RJ (1988) Replacement of amalgams with crowns: a cost-effectiveness analysis. Community Dent Oral Epidemiol 16: 263-267. 
Citation: Nikolopoulou E, Loukidis M (2014) Critical Review and Evaluation of Composite/Ceramic Onlaysversus Crowns. Dentistry 4: 261. doi: $10.4172 / 2157-7633.1000261$

Page 6 of 6

66. Kelly PG, Smales RJ (2004) Long-term cost-effectiveness of single indirect restorations in selected dental practices. Br Dent J 196: 639-643.

67. Mjör IA (1992) Long term cost of restorative therapy using different materials. See comment in PubMed Commons below Scand J Dent Res 100: 60-65.
68. Lehner CR1, Schärer P (1992) All-ceramic crowns. CurrOpin Dent 2: 45-52.

69. Thornton J (2014) Mechanical properties of dental resin composite CAD/CAM blocks Master of science. 